\title{
Prof. Diana Baptiste: study in different ways to help our patients, families and communities get better
}

Received: 21 November 2018; Accepted: 10 December 2018; Published: 12 December 2018.

doi: $10.21037 /$ shc. 2018.11 .08

View this article at: http://dx.doi.org/10.21037/shc.2018.11.08

\section{Editor's note}

From November $2^{\text {nd }}$ to $3^{\text {rd }}, 2018$, the $1^{\text {st }}$ China-Eastern Europe International Forum on Thoracic Disease, jointly sponsored by Shanghai Chest Hospital, Shanghai Hospital Association, and First Faculty of Medicine, Charles University in Prague, was successfully held in Shanghai. The conferences gathered well-known experts at home and abroad to share and discuss hot topics on chest disease to promote academic exchanges. On this conference, Professor Diana Baptiste gave an excellent presentation, titled "enhancing cardiovascular outcomes through nursing research, quality improvement, and evidence-based practice" (Figure 1).

During the conference, the editorial office of Shanghai Chest had the great honor to do an interview with Prof. Diana Baptiste (Figure 2).

\section{Expert's introduction}

A registered nurse for more than 15 years, Diana Baptiste (Figure 3) specializes in cardiovascular health care and prevention in underserved populations. She has focused her scholarship on translating evidence-based practice to improve self-care behaviors among adults living with heart failure. She recently expanded her clinical practice to the Johns Hopkins Hospital adult emergency department, where she serves as an evidence-based practice nurse consultant, guiding the development of quality improvement projects and publications for the department. She has presented nationally, internationally and published peer-reviewed papers in areas of heart failure and cultural humility. Dr. Baptiste teaches in courses across all levels of the pre-licensure nursing program. She is currently serving as the President of the Nu Beta chapter for the Sigma Theta Tau International Honor Society and is dedicated to promoting diversity and inclusion.

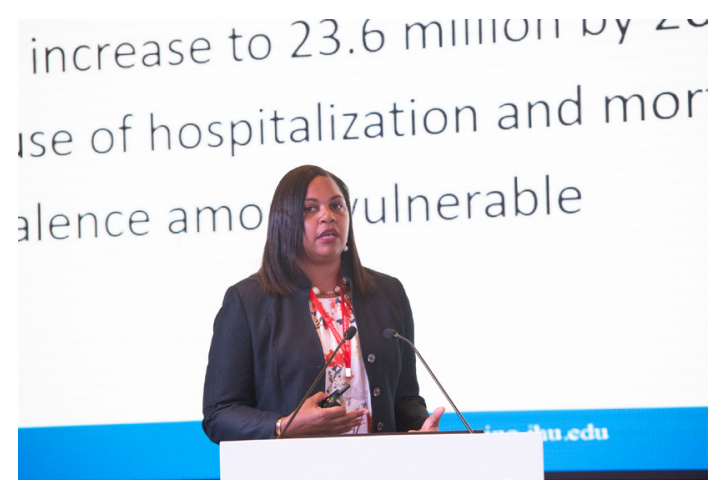

Figure 1 Picture of Prof. Diana Baptiste's presentation.

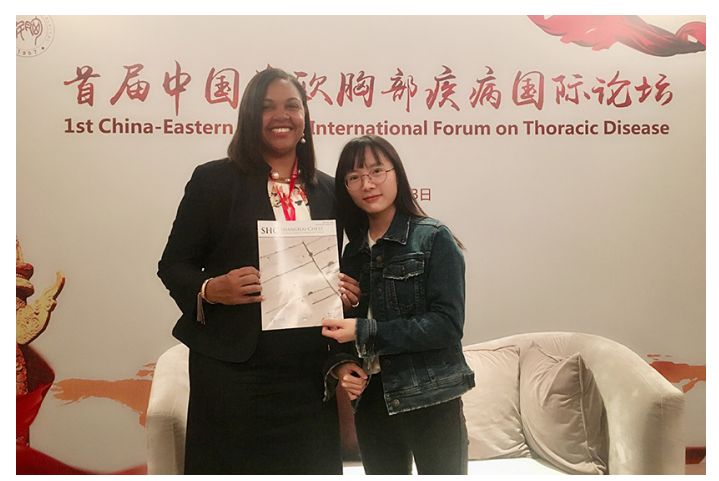

Figure 2 Photo with Prof. Diana Baptiste. From left to right: Prof. Diana Baptiste, editor Hailing Lian.

\section{Interview (Figure 4)}

SHC: Could you share the highlight of your presentation that you have shared at this conference for our readers?

Prof. Baptiste: My presentation today was titled "enhancing cardiovascular outcomes through nursing research, quality improvement, and evidence-based practice". In my presentation, I talked about cardiovascular research, 


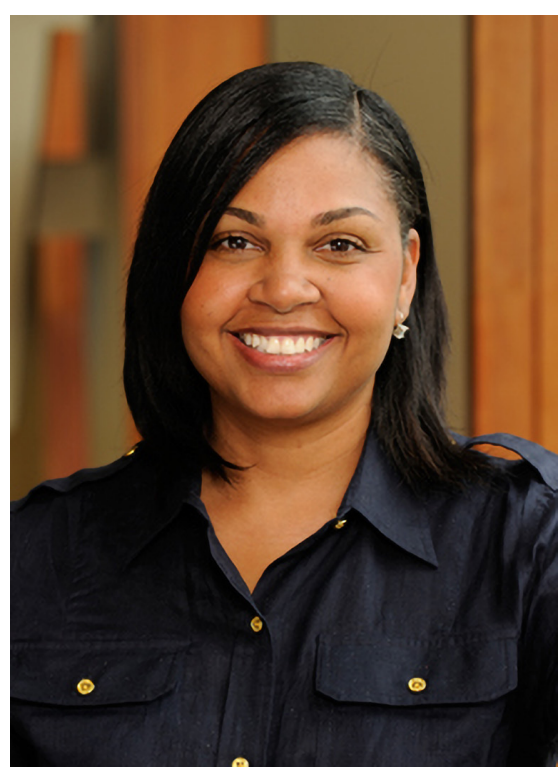

Figure 3 Prof. Diana Baptiste.

because that is what I do. My main research is focused on heart failure and cardiovascular-related emergency room visits. But more so for the nurses here, I didn't focus on my local work, because I really wanted to speak to the global audiences. Therefore, I talked about cardiovascular outcomes globally and how cardiovascular disease is a problem all over the world and how people are dying every day of cardiovascular disease. In my talk, I wanted to speak to nurses about using nursing inquiry in the form of either quality improvement, evidence-based practice or research to improve cardiovascular outcomes. I spoke about the methods that we use at Johns Hopkins University, which is the Johns Hopkins evidence-based nursing model. I also talked about different types of research and using tools and checklists to make sure that your research is robust and that it's done with integrity and that includes patients' outcomes.

\section{SHC: As a registered nurse for more than 15 years, can you talk about the difficulties or challenges you've encountered during your career? How do you overcome it?}

Prof. Baptiste: Basically, challenges of clinical nurse are not being a control of everything. We want all of our patients to be well, but the reality is that it's inevitable that patients do die sometimes and sometimes our interventions don't always work. So, I think that is the biggest challenge for me and that's the impetus for me to go into nursing research

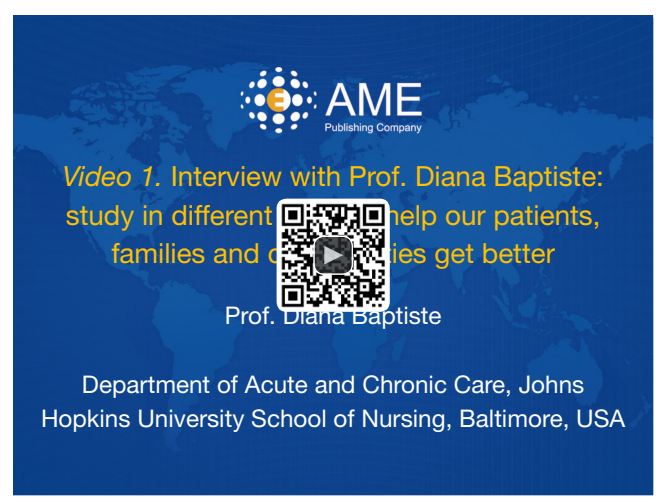

Figure 4 Interview with Prof. Diana Baptiste: study in different ways to help our patients, families and communities get better (1). Available online: http://www.asvide.com/article/view/28808

and pursue my doctorate as a nurse, because I want to make an impact on a different level. I still like to be very involved in patients care but $\mathrm{I}$ also feel like informing patients care through research and clinical research and evidence-based practice is also important, so that's my dedication and that's the way that I overcome the challenges. That is by studying different ways to help our patients, families, and communities get better.

\section{SHC: Is there a particular achievement you are proudest of in your career so far?}

Prof. Baptiste: I really feel like this is my proudest moment, being here in Shanghai, China to speak to the nurses at Shanghai Chest Hospital. This is a wonderful achievement for me and I hope to have more opportunities to speak globally. I feel like we do wonderful work at Johns Hopkins University, School of Nursing and at the Johns Hopkins Hospital. It's very important that we disseminate the work across the world, so this is a very great reward for me.

\section{SHC: I know that you serve as an evidence-based practice nurse consultant at fohns Hopkins Hospital adult emergency department, and you have presented nationally, internationally and published peer-reviewed papers, and you also teach in courses across all levels of the pre- licensure nursing program. How do you allocate your time and energy?}

Prof. Baptiste: I do have a lot of jobs within my role as an assistant professor at Johns Hopkins, so my role is to publish 
papers, to guide evidenced-based practice in the emergency department, Johns Hopkins Hospital, and also to teach the students in free licensure program. My calendar is my best friend. I organize as much as I possibly can. Sometimes I actually use project management tools to organize my tasks and my timeline, so that I can meet my deadlines and that helps me feel less stressed about the work that I have to deliver. So, it's just keeping organizing my calendar, using project management tools and also assembling teams to help me. My greatest work comes out when I work with students, because the students are very energetic. They're very happy to do this type of work, so I do get a lot of great students. Sometimes I am able to fund a student but even if I'm not, students will typically volunteer to help me get the work done, which is a wonderful thing because it's a dual benefit, for I benefit by doing my research, and they learn so much and they get the opportunity to publish, which is a great thing to do while you're a student. So, that's how I divide all of my many jobs within the One Bowl at Johns Hopkins School of Nursing.

\section{SHC: May I know something about yourself that many people may not know?}

Prof. Baptiste: I love music of all kinds and I like music from 1960s, 1970s, 1980s and a little bit of 1990s, so I collect vinyl records. I go to these new stores to look for records and I buy them for like a dollar each. That's my hobby and I really enjoy collecting old records.

\section{Acknowledgments}

Funding: None.

doi: $10.21037 /$ shc. 2018.11 .08

Cite this article as: Lian H. Prof. Diana Baptiste: study in different ways to help our patients, families and communities get better. Shanghai Chest 2018;2:93.

\section{Footnote}

Provenance and Peer Review: This article was commissioned by the Editorial Office, Shanghai Chest. The article did not undergo external peer review.

Conflicts of Interest: The author has completed the ICMJE uniform disclosure form (available at http://dx.doi. org/10.21037/shc.2018.11.08). The author has no other conflicts of interest to declare.

Ethical Statement: The author is accountable for all aspects of the work in ensuring that questions related to the accuracy or integrity of any part of the work are appropriately investigated and resolved.

Open Access Statement: This is an Open Access article distributed in accordance with the Creative Commons Attribution-NonCommercial-NoDerivs 4.0 International License (CC BY-NC-ND 4.0), which permits the noncommercial replication and distribution of the article with the strict proviso that no changes or edits are made and the original work is properly cited (including links to both the formal publication through the relevant DOI and the license). See: https://creativecommons.org/licenses/by-nc-nd/4.0/.

\section{References}

1. Lian H. Interview with Prof. Diana Baptiste: study in different ways to help our patients, families and communities get better. Asvide 2018;5:906. Available online: http://www.asvide.com/article/view/28808

(Science Editor: Hailing Lian, SHC, shc@amegroups.com) 